\section{Roan Translocation in Kenya}

Ranka Sekulic

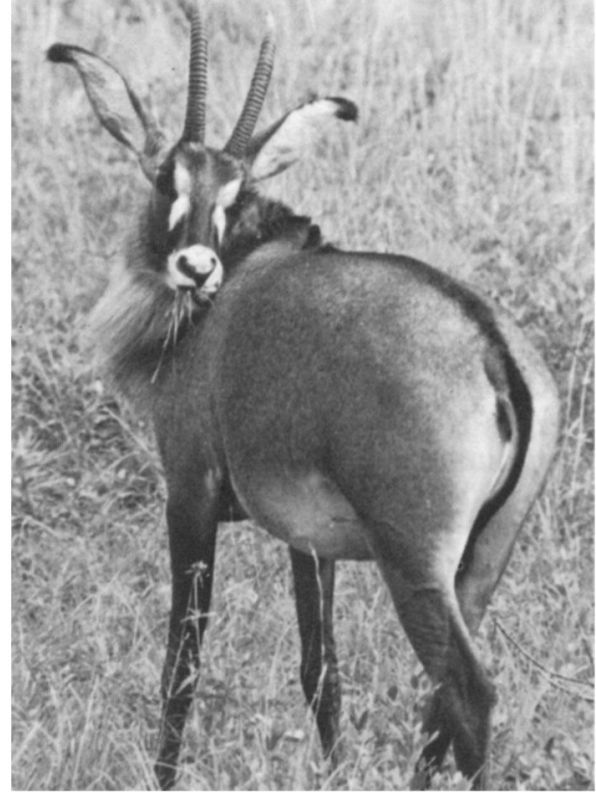

Between 1970 and 1972 the East African Wildlife Society removed 38 roan antelope to the Shimba Hills National Reserve, near Mombasa, because their habitat in central Kenya was about to be destroyed. Since then the author has visited the reserve several times to study the roan. In 1973 she could find only eight; in 1976 there were 13, but by 1978 numbers had risen to 22 . She suggests that, while most of the practical problems of translocating wild animals have been solved, there are many species about whose social organisation very little is known, and this may have been the main reason for the initial lack of success with the roan. But now they are threatened by the Forest Department's policy of planting the grasslands with pines.

Roan Hippotragus equinus are widespread in Africa south of the Sahara, but everywhere declining in numbers. Once they were plentiful in south-west Kenya and also found in several localities in central Kenya:13 today the estimated total for the whole country is only 300 . The largest population is in the Lambwe Valley Game Reserve, near Lake Victoria, where about 200 have survived despite heavy poaching, and some inhabit the western end of the Mara Game Reserve and the adjoining Soit Ololol escarpment. Until the 1977 hunting ban they were sought by professional hunters, despite their critically low numbers and full protection. A stuffed roan was one of the animals sent to President Marcos of the Philippines in 1976, and in August and September that year a roan head was on display in the Zanzibar Curio Shop in Mombasa. I could not trace the origin of these animals, but they were probably taken at the Soit Ololol escarpment, which has been a popular hunting area for over 20 years. The roan, one of the handsomest African ungulates, is the second largest African antelope, measuring 125 to 160 centimetres at the shoulder and weighing 225 to 275 kilograms. Its coat is rufous-grey to light reddish-brown, 
with white underparts; a well-developed mane runs from nape to shoulder, and long hair under the neck forms a kind of ruff. Face markings are very conspicuous: the blaze and sides of the face are black, with a broad pure white stripe over the eye from the base of the horn to the cheek, and white muzzle. The ears are long and pointed with tufted tips. Male horns are 75 to 100 centimetres long, ringed and curved backwards; those of females are similar but somewhat smaller. ${ }^{1}$

At the beginning of the decade, close to 100 roan on a large ranch in the Ithanga Hills, between the towns of Thika and Meru, were threatened with extermination by a scheme to develop their habitat as farmland. The East African Wild Life Society decided to translocate them to the Shimba Hills National Reserve near the coast, south-west of Mombasa, although there is no evidence that roan ever inhabited the region. It was considered suitable because it was the home of the congeneric sable antelope Hippotragus niger, which coexists with roan in many parts of Africa, and because of the scarcity of large predators, notably lions.

Shimba Hills National Reserve is part of a dissected plateau of some 250 square kilometres, rising from the coastal plain to over 500 metres. It is an island of uninhabited land in a heavily populated area, and some 200 sable live there, probably the only surviving sable in Kenya. The reserve is about equally divided between grassland and patches of tropical forest, some of the last surviving coastal forest. The area was demarcated as a forest reserve as early as 1903 , and since the 1940 s grassland has steadily been replaced with plantations of exotic softwoods, especially Pinus caribaea. Despite the gazetting of the Shimba Hills as a national reserve in 1968, under the administration of National Parks, the Forest Department has continued the logging and planting programme laid down under British colonial administration, disregarding the great value of the reserve for wildlife conservation and tourism, and even ignoring its vital importance as a water catchment area for the coastal resorts.

The roan translocation was one of the biggest projects ever undertaken by the East African Wild Life Society, costing over $£ 12,000$. Horses, trucks and a helicopter were used to drive the roan towards mile-long catching wings which funnelled into a $2 \frac{1}{2}$-acre corral. They were then taken in trucks to the Shimba Hills and kept in a 30 -acre corral until release; 38 had been released by early $1972 .{ }^{10}$

Between June 1973 and January 1978 I studied the roan and the sable during several periods. In June 1973 as few as eight of the original roan may have been in the reserve; by June 1974 only seven remained plus two calves born in 1973, making nine. There were no additional young in 1974. The situation was critical and I recommended that the animals be recaptured and only released when numbers had built up again. However, in 1975 and 1976 six young were added (two of which disappeared at the age of about 5 months), and in September 197613 roan were counted.

During the December 1977/January 1978 observations I found that all the known individuals had survived, and that females born in 1973 already had calves. Nine additional young had been born since September 1976, bringing the total to 22: 2 adult males (one of which fathered all the offspring), 8 adult females, two 2-year females, 4 yearlings ( 3 of them male) and 6 calves ( 3 of them male). Unfortunately more grassland has been planted with pines, and the reserve's future is in jeopardy if this policy is not changed. 


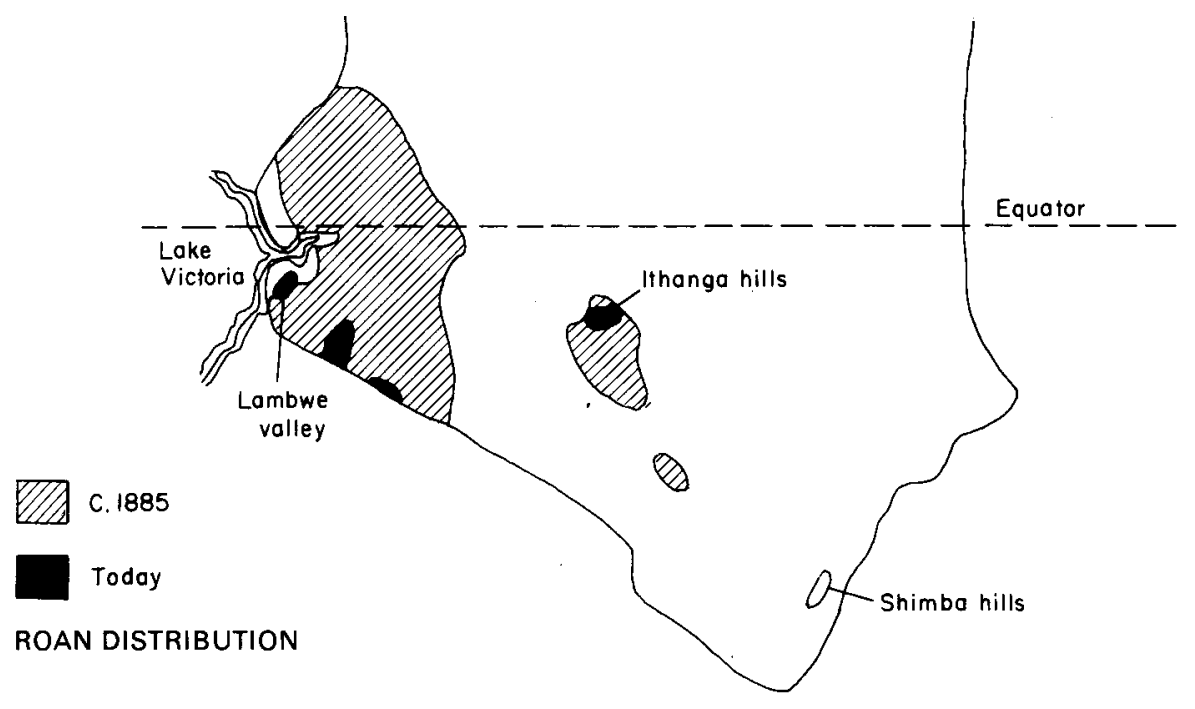

\section{Social Organisation and Reproduction}

Sable and roan are the only living species of the genus Hippotragus. A third, the blaauwbok Hippotragus leucophaeus, once inhabited the Cape Province of South Africa, but was never seen after 1800 and was thus the first historically recorded African mammal to become extinct. ${ }^{8}$

The social organisation of sable and roan appears to be similar, except that sable may be found in herds of over 70 while roan rarely run in herds of more than 30 . Each herd is led by a senior female, and will not mix readily with members of other herds. Joubert ${ }^{9}$ says that roan run in small herds in which family ties play an important role; I myself have observed antagonism between members of different sable herds and overlap in home ranges of only 20 per cent. Sable males are territorial, defending an area of $25 \mathrm{ha}^{7}$ to several square kilometres, ${ }^{5}$ and roan males are probably territorial as a rule. ${ }^{3}$ Territorial males are highly antagonistic towards each other and Grobler reports that fighting between sable males may result in death. The territorial males evict the young males from a herd at between three and four years of age; these usually form bachelor herds of not more than 10 animals al though I have seen a roan bachelor herd of 17 in Kenya's Lambwe Valley National Reserve.

Most of the translocated roan females and young were found in a single herd, which frequently broke up into smaller groups, ranging in an area of about $15 \mathrm{sq} \mathrm{km}$. One female stayed alone, in a different area, al though she was seen several times in the vicinity of the herd, until, at the end of 1976 , she joined the others and began to reproduce. The two adult bulls were never seen together, and their distribution and marking behaviour suggested territoriality.

Under ideal conditions, roan would be expected to have calves at intervals of 10 months, ${ }^{9}$ a pattern also found in the Shimba Hills sable. Shortly before giving birth the females leave the herd and do not return until the calf is four to six weeks old. All except one of the translocated roan, which was still very young, appeared to give birth at least once a year. Thus between 1973 and 1976, more than 15 calves must have been born, of which only one-third survived to the age of nine months. It appears that all calves born after September 1976 have survived. 


\section{Discussion}

An obvious question of concern is why, two years after the translocation, only eight of the original 38 roan were still in the reserve. Most of the animals apparently disappeared shortly after the introduction. Although the roan were in poor condition during the one dry season that I spent there, low adult mortality after 1973 (only one adult female) and reports of roan outside the reśerve suggest that their disappearance was due to failure to settle and not to death through disease. Several reasons may have been responsible for the scatter. Because of tick infestation while they were in the Shimba Hills enclosure the roan were released before they became familiar with the area. This could have been avoided by building an enclosure of at least 100 acres, as Estes recommended. ${ }^{2} \mathrm{He}$ also pointed out that acclimatisation and knowledge of the home range are essential for survival and must be taken into account.

Roan social structure - or lack of it in the case of the translocated animals may have been even more important. Roan from different herds, as well as territorial bulls, were put into the same enclosure, and fighting between groups resulted in the death of at least three animals. ${ }^{10}$ The roan female that stayed alone for three years may show how resistant individuals are to associating with animals from other herds. Thus, in addition to capture and translocation, these roan had to undergo the traumatic experience of enforced association with individuals they would normally avoid. Release of the roan from different herds in the same area could also have contributed to the initial dispersal, as each group tried to establish a distinct home range. Placing each group in an enclosure in a different area might have averted this problem.

Moreover, four lions were reported in the Shimba Hills until 1973 but not thereafter. No kills were ever recorded, but they frequently disturbed the sable $^{6}$ and could have easily accounted for some of the missing roan. The size and the pugnacity of these antelopes would make it difficult for a leopard, the other large predator, to kill an animal older than two years. But sable calves have been taken by leopard ${ }^{4.6}$ and some roan calves may have died through leopard predation. Nervous behaviour could also have contributed to the calves' high mortality. Unlike sable, roan were of ten observed to run away from unknown disturbances, resulting in break-ups of the herd. Study of their daylight activity patterns showed that roan spent about twice as much time as sable in standing and watching, and only two-thirds as much time grazing. This suggests that it may have taken the translocated roan a long time to feel 'at home'.

The Shimba Hills roan may now have passed through the critical acclimatisation period. As Joubert points out, ${ }^{9}$ roan under favourable conditions should be able to increase rapidly despite critically small populations. It may be advisable at a later date to introduce additional roan bulls in the Shimba Hills to increase variability in the genetic stock. The roan is an added attraction to this reserve and it can only be hoped that the Forest Department's activities will not jeopardise its continued existence. Good observational conditions and the tameness of sable and roan make the Shimba Hills an excellent location to study them. Interesting interactions between the two species have already been observed, ${ }^{12}$ as well as an instance of adoption of a roan calf by another female in the group. ${ }^{11}$

Many of the practical problems of capture and translocation of wild animals have been overcome, and the missing key to successful translocation 
may be understanding of the social organisation. Most studies of gregarious mammals show that their groupings are not random but complex societies based on kinship ties. ${ }^{14}$ It may be that ignorance of roan social organisation and premature release of the animals was responsible for the near failure of the translocation.

\section{Acknowledgments}

I would like to thank the Kenya Government and Dr P. M. Olindo, former director of Kenya National Parks, for permits to conduct research in the Shimba Hills. The tinancial support for the field work was provided by the East African Wild Life Society, the National Geographic Society (R. D. Estes, Principal Investigator), and the Sigma Xi (the Scientific Research Society of North America). The Smithsonian Institution lent me a Land Rover for a part of the study. I am grateful to P. Mulandi, the former Game Warden of the Shimba Hills National Reserve, for his assistance on many occasions. Without the encouragement of Dr R. D. Estes and help from my parents this study would not have been possible. I thank Dr R. D. Estes for his comments on the first draft of this manuscript.

\section{References}

1. DORST, J. \& DANDEL,OT, P. 1970. A Field Guide to the Larger Mammals of Africa. London: Collins. $287 \mathrm{pp}$.

2. ESTES, R.D. 1969. Status of the roan antelope on the Tana Ranch. Report to the Game Department, Kenya. 6 pp.

3. 1974. Social organisation of the African Bovidae. In V. Geist \& F. Walther, eds., The Behaviour of Ungulates and its Relation to Management, vol. 1, pp. 166-205.

4. \& ESTES, R.K. 1969. The Shimba Hills sable population. Progress report to the National Geographic Society. 34 pp.

5. __ 1974. The biology and conservation of the giant sable antelope (Hippotragus niger variani, Thomas, 1916). Proc. Acad. Nat. Sci. Phila., 126(7): 73-104.

6. GLOVER, P.E. 1969. Report on an ecological survey of the proposed Shimba Hills National Reserve. East African Wild Life Society. 148 pp.

7. GROBLER, J.H. 1974. Aspects of the biology, population ecology and behaviour of the sable Hippotragus niger niger (Harris, 1838) in the Rhodes Matopos National Park, Rhodesia. Arnoldia Rhod., 7(6): 1-36.

8. HARPER, F. 1945. Extinct and Vanishing Mammals of the Old World. American Committee for International Wildlife Protection, New York, Spec, publ. no. 12. $\mathrm{xv}+850 \mathrm{pp}$.

9. JOUBERT, S.C.J. 1970. A study of the social behaviour of the roan antelope, Hippotragus equinus equinus (Desmarest, 1804) in the Kruger National Park. M.Sc. Thesis, Univ. of Pretoria, 205 pp.

10. PARKINSON, T. 1972. The roan story. Africana, 4(9): 15.

11. SEKULIC, R. 1976. A case of adoption in the roan antelope, Hippotragus equinus (Desmarest, 1804), in Kenya. Sauget. Mitt., 24(3): 235-238.

12. 1978. A note on interactions between sable (Hippotragus niger) and roan (Hippotragus equinus) in Kenya. J. Mammal. 59(2): 444-446.

13. STEWART, D.R.M. \& STEWART, M. 1963. Past and present distribution of some East African mammals. East Africa and Uganda Nat. Hist. Soc. J., 24(3): $1-48$.

14. WILSON, E.O. 1975. Sociobiology: The New Synthesis. Cambridge, Mass: Harvard University and the Belknap Press. ix $+697 \mathrm{pp}$.

Author: Dept. of Zoology, University of Maryland, College Park, Md. 20742, and Office of Zoological Research, National Zoological Park, Smithsonian Institution, Washington DC 20009 